\section{ENVIRONMENTAL RESTORATION PROGRAM}

RECEIVED

AUG 201996

OSTI
This document has been approved by the ORNL Technical Information Office for release to the public. Date: Aug, 5, 1986

DISTRIBUTION OF THIS DOCUMENT IS UNLIATIED

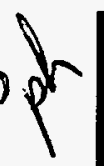

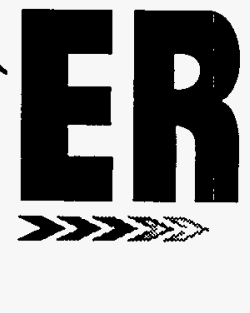




\begin{tabular}{|l|}
\hline $\begin{array}{c}\text { Gilbert/Commonwealth Engineers \& Consultants } \\
\text { and Analysas Corporation }\end{array}$ \\
$\begin{array}{l}\text { contributed to the preparation of this document and should not be } \\
\text { considered eligible contractors for its review }\end{array}$ \\
\hline
\end{tabular}

This report has been reproduced directly from the best available copy.

Available to DOE and DOE contractors from the Office of Scientific and Technical Information, P.O. Box 62, Oak Ridge, TN 37831; prices available from 423-576-8401 (fax 423-576-2865).

Available to the public from the National Technical Information Service, U.S. Department of Commerce, 5285 Port Royal Rd., Springfield, VA 22161. 


\title{
Health and Safety Plan for the Isotopes Facilities Deactivation Project at Oak Ridge National Laboratory Oak Ridge, Tennessee
}

\author{
Environmental Restoration Division \\ P.O. Box 2003 \\ Oak Ridge, Tennessee 37831-7298
}

Date Issued-August 1996

\author{
Prepared for the \\ U.S. Department of Energy \\ Office of Environmental Management \\ under budget and reporting code EW 20 \\ Environmental Management Activities at the \\ OAK RIDGE NATIONAL LABORATORY \\ Oak Ridge, Tennessee 37831-6285 \\ managed by \\ LOCKHEED MARTIN ENERGY SYSTEMS, INC. \\ for the \\ U.S. DEPARTMENT OF ENERGY \\ under contract DE-AC05-84OR21400 \\ for the \\ U.S. DEPARTMENT OF ENERGY
}




\section{DISCLAIMER}

This report was prepared as an account of work sponsored by an agency of the United States Government. Neither the United States Government nor any agency thereof, nor any of their employees, makes any warranty, express or implied, or assumes any legal liability or responsibility for the accuracy, completeness, or usefulness of any information, apparatus, product, or process disclosed, or represents that its use would not infringe privately owned rights. Reference herein to any specific commercial product, process, or service by trade name, trademark, manufacturer, or otherwise does not necessarily constitute or imply its endorsement, recommendation, or favoring by the United States Government or any agency thereof. The views and opinions of authors expressed herein do not necessarily state or reflect those of the United States Government or any agency thereof. 


\section{DISCLAIMER}

Portions of this document may be illegible in electronic image products. Images are produced from the best available original document. 
APPROVALS

Environmental Restoration Program

Health and Safety Plan

for the Isotopes Facilities

Deactivation Project

at Oak Ridge National Laboratory,

Oak Ridge, Tennessee

Rich

$7 / 29 / 96$

Cw. Burnundle

$\varepsilon 1 / 96$

T. W. Burwinkle, Facility Management and Operations Deputy Manager

Date

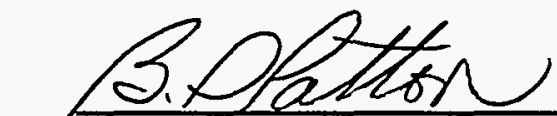

B. D. Patton, Facility Manager

$7-30-96$

Date

Carly Cloth

$8 / 1 / 96$

C. Clark, Jr., Environmental Restoration Health and Safety Representative

Date 


\section{PREFACE}

This health and safety plan (HASP) provides information about potential health and safety hazards that may be encountered during the Isotopes Facilities Deactivation Project at the Oak Ridge National Laboratory. Methods of reducing or preventing exposure to the hazards associated with performing the work activities described in this plan and the project work plan (ORNL/ER-249/R2) are identified in this document. This HASP was developed under Work Breakdown Structure 1.4.12.2.3.03.01.03, Activity Data Sheet 8303. 


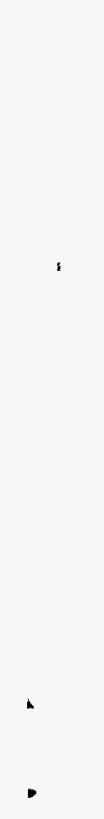




\section{CONTENTS}

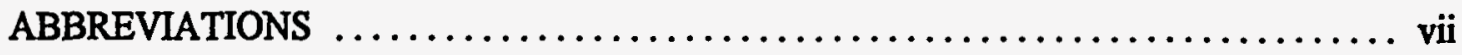

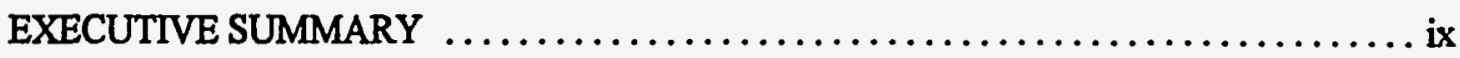

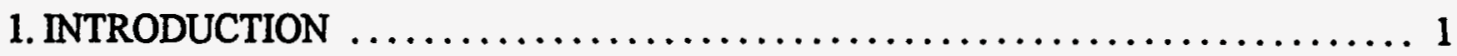

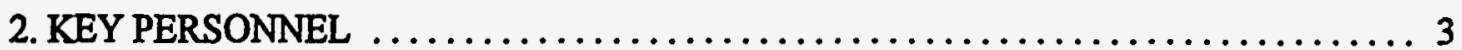

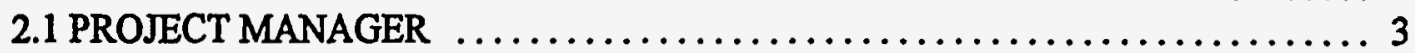

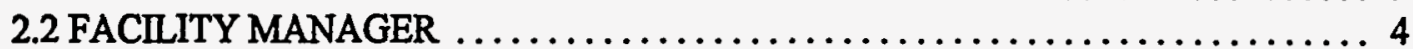

2.3 ER HEALTH AND SAFETY REPRESENTATIVE $\ldots \ldots \ldots \ldots \ldots \ldots \ldots \ldots \ldots 4$

2.4 OFFICE OF SAFETY AND HEALTH PROTECTION REPRESENTATIVE . . . . 4

2.5 SAFETY AND HEALTH EVALUATION AND SUPPORT TEAM

REPRESENTATIVE ............................. 5

2.6 OFFICE OF RADIATION PROTECTION $\ldots \ldots \ldots \ldots \ldots \ldots \ldots \ldots \ldots \ldots \ldots$

2.7 PROJECT HEALTH AND SAFETY OFFICER $\ldots \ldots \ldots \ldots \ldots \ldots \ldots \ldots \ldots \ldots$

2.8 PROJECT PERSONNEL $\ldots \ldots \ldots \ldots \ldots \ldots \ldots \ldots \ldots \ldots \ldots \ldots \ldots \ldots \ldots \ldots$

2.9 LABORATORY SHIFT SUPERINTENDENT $\ldots \ldots \ldots \ldots \ldots \ldots \ldots \ldots \ldots . \ldots$

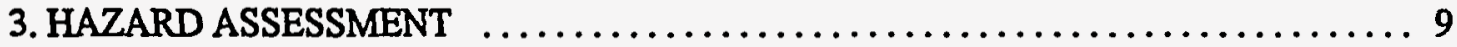

3.1 REMOVAL OF CHEMICAL AND RADIOISOTOPIC INVENTORIES . . . . . . 11

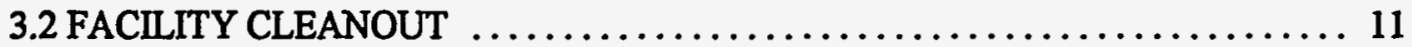

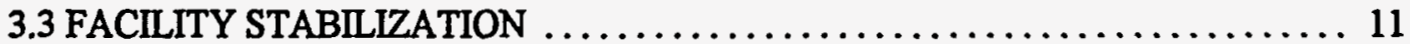

3.4 DEACTIVATION OF HOT CELLS $\ldots \ldots \ldots \ldots \ldots \ldots \ldots \ldots \ldots \ldots \ldots \ldots \ldots$

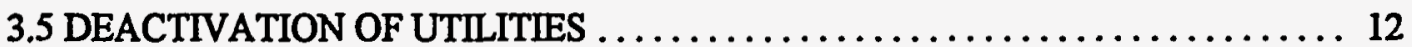

3.6 POTENTIAL CHEMICAL HAZARDS AND CONTAMINANTS $\ldots \ldots \ldots \ldots \ldots 12$

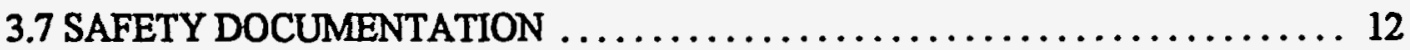

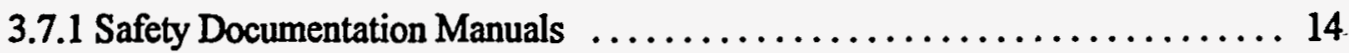

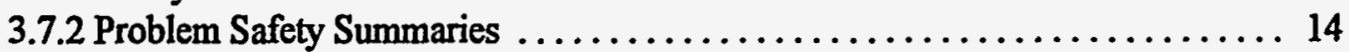

3.7.3 Unreviewed Safety Question Determination .................. 15

3.7.4 As Low As Reasonably Achievable Plans $\ldots \ldots \ldots \ldots \ldots \ldots \ldots \ldots \ldots \ldots$

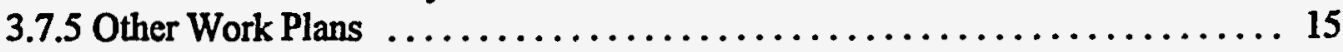

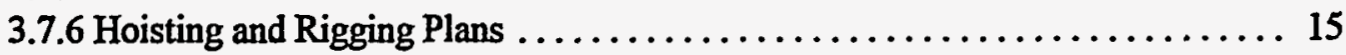

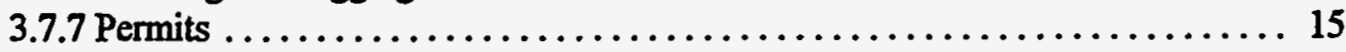

4. TRAINING REQUIREMENTS $\ldots \ldots \ldots \ldots \ldots \ldots \ldots \ldots \ldots \ldots \ldots \ldots \ldots \ldots \ldots \ldots \ldots \ldots \ldots \ldots \ldots \ldots \ldots \ldots$

4.1 GENERAL TRAINING REQUIREMENTS $\ldots \ldots \ldots \ldots \ldots \ldots \ldots \ldots \ldots \ldots \ldots . \ldots \ldots$

4.2 EMERGENCY ACTION PLAN TRAINING $\ldots \ldots \ldots \ldots \ldots \ldots \ldots \ldots \ldots \ldots \ldots$

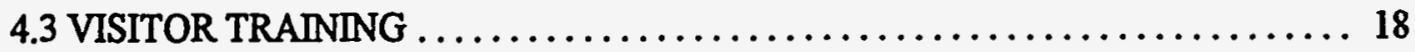




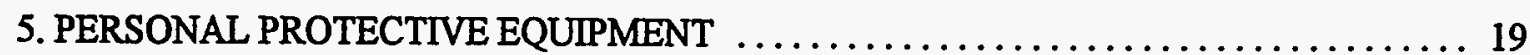

5.1 PPE SELECTION $\ldots \ldots \ldots \ldots \ldots \ldots \ldots \ldots \ldots \ldots \ldots \ldots \ldots \ldots \ldots \ldots, 19$

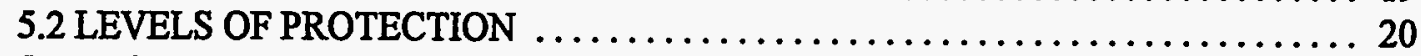

5.3 PROTECTIVE CLOTHING DONNING AND DOFFING PROCEDURES . . . . . 20

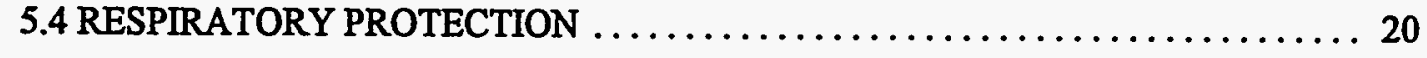

6. MEDICAL SURVELLANCE ................................... 21

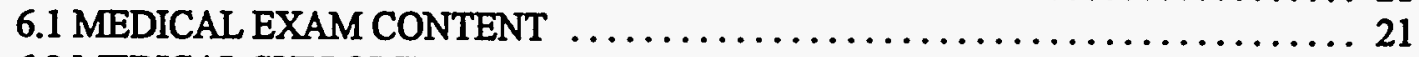

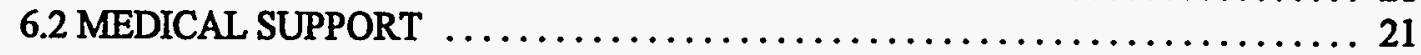

7. EXPOSURE MONITORING AND AIR SAMPLING $\ldots \ldots \ldots \ldots \ldots \ldots \ldots \ldots 23$

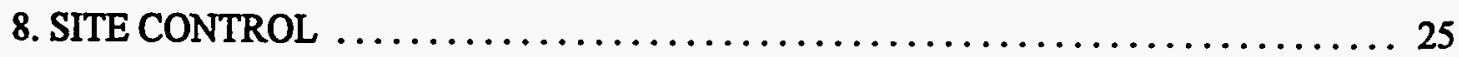

8.1 CONTROL ZONES $\ldots \ldots \ldots \ldots \ldots \ldots \ldots \ldots \ldots \ldots \ldots \ldots \ldots \ldots \ldots \ldots \ldots, 25$

8.2 VISITORS $\ldots \ldots \ldots \ldots \ldots \ldots \ldots \ldots \ldots \ldots \ldots \ldots \ldots \ldots \ldots \ldots \ldots \ldots \ldots \ldots \ldots \ldots \ldots, 25$

9. DECONTAMINATION .................................... 27

10. EMERGENCY RESPONSE/ACTION PLAN $\ldots \ldots \ldots \ldots \ldots \ldots \ldots \ldots \ldots \ldots . \ldots 29$

10.1 EMERGENCY RESPONSE ............................... 29

10.2 LOCAL EMERGENCY MANUALS AND ACTION PLANS $\ldots \ldots \ldots \ldots \ldots \ldots .29$

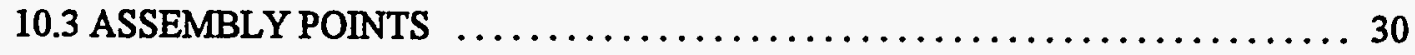

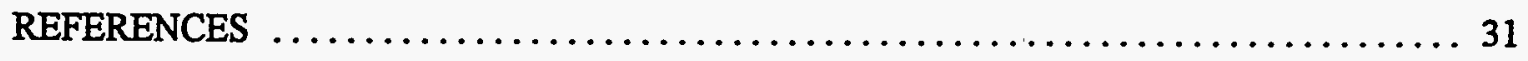




\section{ABBREVIATIONS}

ACM

ALARA

AWR

BIO

CFR

CTD

DOE

ER

GET

HASP

HSD

HSO

IFDP

IH

JHA

FAB

FY

LCD

LMER

LSS

MSDSs

ORNL

ORP

OSHA

OSHP

OSR

PACSE

PEL

PPE

PSS

QA

RBA

RCT

RTS

RWP

SA

SAR

S\&M

SHEST

TLV

USQD

WBGT asbestos-containing material

as low as reasonably achievable

asbestos work request

Basis for Interim Operation

Code of Federal Regulations

Chemical Technology Division

Department of Energy

Environmental Restoration

General Employee Training

health and safety plan

Hazard Screening Document

Health and Safety Officer

Isotopes Facilities Deactivation Project

industrial hygiene

job hazard analysis

Facility Authorization Basis

fiscal year

Limiting Conditions Document

Lockheed Martin Energy Research

Laboratory Shift Superintendent

Material Safety Data Sheets

Oak Ridge National Laboratory

Office of Radiation Protection

Occupational Safety and Health Administration

Office of Safety and Health Protection

Operational Safety Requirement

permit attachment for confined space entry

permissible exposure limit

personal protective equipment

problem safety summary

quality assurance

radiological buffer area

radiological control technician

Radiochemical Technology Section

Radiological Work Permit

safety assessment

Safety Analysis Report

surveillance and maintenance

Safety and Health Evaluation and Support Team

threshold limit value

Unreviewed Safety Question Determination

wet bulb globe temperature 



\section{EXECUTIVE SUMMARY}

This health and safety plan (HASP) describes the process for identifying the requirements, written safety documentation, and procedures that are necessary to protect the personnel involved in the Isotopes Facilities Deactivation Project (IFDP). The key objective of this project is to place 19 former isotope production facilities at the Department of Energy's (DOE's) Oak Ridge National Laboratory (ORNL) in a radiologically, industrially, and environmentally safe condition in anticipation of an extended period of minimum surveillance and maintenance (S\&M). This project will be conducted in a manner that ensures the protection of the safety and health of workers, the public, and the environment. Upon completion of the project, the deactivated facilities will be turned over from the DOE Headquarters Office of Nuclear Materials and Facility Stabilization (EM-60) to the DOE Headquarters Office of Decontamination and Decommissioning Program (EM-40). Deactivation of the IFDP facilities was initiated in fiscal year (FY) 1994 and is scheduled for completion in FY 2000.

The following general tasks are involved in the deactivation process:

- characterize the facility (update radiological surveys, assess facility conditions, and inventory hazardous chemicals and radioactive materials);

- identify the required deactivation activities;

- remove hazardous chemical and radioactive material inventories;

- clean out the facility (removing surplus equipment and wastes);

- stabilize the facility structurally and radiologically (removing transferable and bonding fixed contamination, repairing containment systems, and deactivating hoods and glove boxes);

- deactivate hot cells; and

- deactivate utilities.

For additional project information, see the work plan for the IFDP (ORNL/ER-249/R2) and the project management plan (ORNL/ER-230/R1).

The primary hazards associated with the IFDP include contact with radioisotopes and radiological contamination in facilities, hot cells, and ventilation systems; other hazards associated with the structure of each facility such as asbestos-containing materials and electrical systems; contact with materials used in shielding such as dust from lead bricks, $\mathrm{ZnBr}_{2}$ and mineral oils; and physical hazards such as confined space and deteriorating walking and working surfaces.

Methods of control for these hazards are identified within task-specific procedures for each facility. Additional control methods will be identified in documents such as Asbestos Work Requests (AWRs), Radiological Work Permits (RWPs), Safety Work Permits (SWPs), permit attachments for confined space entry (PACSEs), Problem Safety Summaries (PSSs), and Job Hazard Analyses (JHAs) as appropriate for each task. All work will be performed in accordance with Title 29, Part 1910 and Title 10 Part 835 of the Code of Federal Regulations. 
This HASP is organized as specified in the Annotated Outlines For Documents Required by the Federal Facilities Agreement (FFA) and the Comprehensive Environmental Response, Compensation, and Liability Act (CERCLA) For Oak Ridge Reservation Sites (DOE OR/1077, 1993). This guidance document is administered by the Document Content and Response Committee and is available through the ER Publications Office. 


\section{INTRODUCTION}

The mission of the Isotope Facilities Deactivation Project (IFDP) is to identify, evaluate, and execute the activities required to deactivate the 19 former isotope production facilities listed in Table 1.1 in safe shutdown condition. A deactivated, shutdown facility is one in which

- hazardous materials and wastes and transferable radioactive contamination have been removed from accessible areas,

- containment structures are in sound physical condition,

- energy sources in the building have been de-energized to the maximum extent practical,

- use and occupancy of the building have been terminated, and

- the facility is structurally sound and weather tight.

The facilities are in various states of operation, abandonment, or disrepair and range from isotope experiment and production laboratories and processing stations to storage, handling, packaging, and shipping facilities. See Appendix A, Description and History of Facilities, of the project work plan (ORNL/ER-249/R2) for a detailed description of the Oak Ridge National Laboratory (ORNL) site and of each facility.

The IFDP is managed by the Lockheed Martin Energy Systems Environmental Management and Enrichment Facilities (EM\&EF) organization. EM\&EF has developed a memorandum of agreement with the Lockheed Martin Energy Research (LMER) Chemical Technology Division (CTD)for oversight of routine surveillance and maintenance (S\&M) activities in IFDP facilities along with support from other ORNL organizations. CTD will also perform selected deactivation activities. Subcontractors will be used for deactivation activities as needed.

This HASP has been written for use in conjunction with the project work plan. This plan provides guidance and requirements to ensure that hazard analysis is conducted and appropriate safety documentation is prepared for work activities to protect personnel who are conducting this work. The Radiological Work Permit (RWP) system will be used to identify radiological hazards and prescribe required work practices, monitoring, personal protective equipment (PPE), and methods of control for specific work locations within each facility. Where in existence, building-specific standard operating procedures will be followed or modified for project tasks.

Additional forms of health and safety documentation will be developed and followed as applicable to each area and task. These may include, but are not limited to Safety Work Permits (SWPs), Lockout/Tagout Permits, job hazard analyses (JHAs), Problem Safety Summaries (PSSs), Excavation/Penetration Permits, and Permit Attachments for Confined Space Entry (PACSEs). All work will be performed in accordance with Title 29 Part 1910 and Title 10 Part 835 of the Code of Federal Regulations (CFR). 
Table 1.1 Facilities scheduled for shutdown

\begin{tabular}{|c|c|c|}
\hline Building Name & Building No. & $\begin{array}{l}\text { Isotopes Formerly } \\
\text { Stored, Used, or Produced } \\
\end{array}$ \\
\hline Krypton-85 Enrichment Facility & $3026-\mathrm{C}$ & $\begin{array}{l}{ }^{129} \mathrm{I},{ }^{131}{ }^{79},{ }^{7 e},{ }^{107} \mathrm{Pd},{ }^{147} \mathrm{Pm},{ }^{137} \mathrm{Cs},{ }^{90} \mathrm{Sr} \\
\text { actinides, }{ }^{85} \mathrm{Kr}, \mathrm{U},{ }^{99} \mathrm{Tc},{ }^{60} \mathrm{Co}, \mathrm{Pu},{ }^{3} \mathrm{H}\end{array}$ \\
\hline Metal Segmenting Facility & 3026-D & ${ }^{99} \mathrm{~T},{ }^{147} \mathrm{Pm},{ }^{137} \mathrm{~Np},{ }^{32} \mathrm{P},{ }^{131} \mathrm{I},{ }^{135} \mathrm{Xn},{ }^{140} \mathrm{Ba},{ }^{60} \mathrm{Co}$ \\
\hline Alpha Powder Facility & 3028 & ${ }^{131} \mathrm{I},{ }^{133} \mathrm{Xe},{ }^{212214} \mathrm{Cm},{ }^{147} \mathrm{Pm},{ }^{99} \mathrm{Mo},{ }^{238} \mathrm{Pu}$ \\
\hline Source Development Laboratory & 3029 & ${ }^{192} \mathrm{Ir},{ }^{60} \mathrm{Co},{ }^{137} \mathrm{Cs},{ }^{90} \mathrm{Sr},{ }^{131} \mathrm{I}_{2}, \mathrm{CH}_{3}{ }^{131} \mathrm{I},{ }^{14} \mathrm{C},{ }^{99} \mathrm{Tc}$ \\
\hline Radioisotope Production Laboratory - C & 3030 & $\begin{array}{l}{ }^{56} \mathrm{Co},{ }^{57} \mathrm{Co},{ }^{198} \mathrm{Au},{ }^{55} \mathrm{Fe},{ }^{234} \mathrm{~Np},{ }^{75} \mathrm{Se} \\
{ }^{90} \mathrm{Sr} \text { nitrate, }{ }^{110} \mathrm{Sn},{ }^{237} \mathrm{U},{ }^{33} \mathrm{P},{ }^{192} \mathrm{Ir},{ }^{63} \mathrm{Ni}\end{array}$ \\
\hline Radioisotope Production Laboratory-D & 3031 & ${ }^{90} \mathrm{Y},{ }^{153} \mathrm{Gd}$ \\
\hline Radioisotope Production Laboratory $-\mathrm{H}$ & 3118 & $\mathrm{NE}$ \\
\hline Radioactive Gas Processing Facility & 3033 & ${ }^{3} \mathrm{H},{ }^{85} \mathrm{~K},{ }^{14} \mathrm{C}$ \\
\hline Radioactive Production Laboratory Annex & 3033-A & $\begin{array}{l}{ }^{14} \mathrm{C},{ }^{241} \mathrm{Am},{ }^{237} \mathrm{~Np}{ }^{238} \mathrm{Pu} \text {, highly enriched } \\
\text { actinide isotopes }\end{array}$ \\
\hline Alpha Handling Facility & 3038-AHF & $\begin{array}{l}{ }^{252} \mathrm{Cf},{ }^{244} \mathrm{Cm},{ }^{241} \mathrm{Am},{ }^{238} \mathrm{Pu},{ }^{234} \mathrm{U},{ }^{237} \mathrm{~Np},{ }^{231} \mathrm{~Pa} \text {, } \\
\text { and others }\end{array}$ \\
\hline Radioisotope Packaging and Shipping Facility & 3038-M & ${ }^{129} \mathrm{I},{ }^{137} \mathrm{Cs},{ }^{60} \mathrm{Co},{ }^{90} \mathrm{Sr},{ }^{99} \mathrm{Tc},{ }^{89} \mathrm{Mn},{ }^{106} \mathrm{Ru},{ }^{36} \mathrm{Cl}$ \\
\hline Isotope Materials Laboratory & 3038-E & $\begin{array}{l}\text { transuranics, }{ }^{90} \mathrm{Y},{ }^{235} \mathrm{U},{ }^{147} \mathrm{Pm},{ }^{90} \mathrm{Sr},{ }^{214} \mathrm{Cm}, \\
{ }^{211} \mathrm{Am}\end{array}$ \\
\hline Isotope Technology Building & 3047 & ${ }^{14} \mathrm{C},{ }^{152 / 154} \mathrm{Eu},{ }^{60} \mathrm{Co},{ }^{153} \mathrm{Gd},{ }^{241} \mathrm{Am},{ }^{212} \mathrm{Cm},{ }^{243} \mathrm{Cm}$ \\
\hline Fission Products Development Laboratory & 3517 & $\begin{array}{l}{ }^{90} \mathrm{Sr},{ }^{137} \mathrm{Cs},{ }^{141} \mathrm{Ce},{ }^{147} \mathrm{Pm},{ }^{106} \mathrm{Ru},{ }^{99} \mathrm{Tc},{ }^{60} \mathrm{Co}, \\
{ }^{192} \mathrm{Ir},{ }^{235} \mathrm{U},{ }^{152 / 154} \mathrm{Eu},{ }^{241} \mathrm{Am}\end{array}$ \\
\hline Tritium Target Preparation Facility & 7025 & ${ }^{3} \mathrm{H}, \mathrm{ThO}_{2}, \mathrm{UO}_{2},{ }^{90} \mathrm{Sr},{ }^{137} \mathrm{Cs},{ }^{244} \mathrm{Cm}$ \\
\hline Radioisotopes Production Laboratory-E & 3032 & ${ }^{241} \mathrm{Am},{ }^{137} \mathrm{Cs},{ }^{235} \mathrm{U},{ }^{60} \mathrm{Co},{ }^{133} \mathrm{Ba},{ }^{233} \mathrm{Pu},{ }^{152 / 154} \mathrm{Eu}$ \\
\hline Radioisotopes Area Services & 3034 & $\begin{array}{l}\text { NE (former field shop for Plant \& Equipment } \\
\text { Division support) }\end{array}$ \\
\hline Storage Cubicle* & 3093 & ${ }^{85} \mathrm{Kr}$ \\
\hline Storage Pad* & 3099 & N/A \\
\hline
\end{tabular}




\section{KEY PERSONNEL}

Table 2.1 shows key project personnel and affiliations for this project. The ultimate responsibility for meeting goals and implementing this project rests with the Environmental Restoration (ER) Program.

Table 2.1. Key project personnel and affiliations

\begin{tabular}{llll}
\hline Responsibility & Name & Telephone & Pager \\
\hline Project Manager & R. E. Eversole & $576-7483$ & $873-5393$ \\
Facility Manager & B. D. Patton & $576-0603$ & \\
Asst. Facility Managers & K. W. Haff & $574-7096$ & $873-9258$ \\
& H. X. Phillips & $574-7047$ & $873-4886$ \\
ER Health and Safety Representative & C. Clark & $574-8268$ & $873-4804$ \\
Office of Safety and Health Protection & B. A. Owen & $574-6883$ & $873-6433$ \\
Representative & & & \\
Safety and Health Evaluation Support & D. A. White & $574-1482$ & $873-6483$ \\
Team Representative & & & \\
Office of Radiation Protection (ORP) & J. R. Slaten & $576-1752$ & $873-5350$ \\
Area Supervisor & & & \\
ORP Area Supervisor & L. Sowder & $574-6709$ & \\
Project Health and Safety Officer & C. Clark & $574-8268$ & $873-4804$ \\
Laboratory Shift Superintendent & Not applicable & & $574-6606$ \\
\hline
\end{tabular}

\subsection{PROJECT MANAGER}

The project manager has overall responsibility for project design and direction. This includes

- maintaining project costs and schedule;

- coordinating efforts with various plant organizations;

- providing budget forecasts and resource commitments;

- ensuring adherence to the health and safety plan (HASP) throughout the project;

- ensuring a process for ensuring that all necessary permits such as RWPs, Safety Work Permits (SWPs), and Asbestos Work Requests (AWRs) have been generated and approved and are in place;

- ensuring that readiness reviews are conducted, where required;

- maintaining required records;

- ensuring that the appropriate safety documentation is prepared or is in place for this project; and

- interfacing with the DOE facility representative, as appropriate. 


\subsection{FACILITY MANAGER}

The facility manager is a designated LMER employee who is primarily responsible for the oversight and coordination of all operations and activities at their facility. The responsibilities of the facility manger include, but are not limited to, the following:

- maintaining an awareness of the status of the assigned facility, including a general knowledge of current and planned research, experimental activities, and operations and maintenance;

- ensuring that operations and maintenance involving radioactive, hazardous material, and energy sources are conducted safely and in compliance with applicable environmental, safety, and health standards;

- knowing and understanding the requirements for permits such as RWPs, SWPs, and lockout/tagout and ensuring that appropriate facility permits are initiated, approved, issued, and followed;

- maintaining the status of, and ensuring documented compliance with, facility safety documentation including technical specification and operational safety requirements;

- ensuring that action is initiated to review and to revise safety documentation as necessary;

- ensuring that facility access training requirements are adequate and that visitors without access training are properly escorted;

- ensuring that all changes to the project within his or her facility (e.g., operational, procedural, or maintenance) are reviewed for unreviewed safety questions per Department of Energy (DOE) Order 5480.21, Unreviewed Safety Questions (USQ);

- ensuring that quantities of radioactive and hazardous materials maintained within the facility are known, documented, and are within applicable limits;

- ensuring that current boundaries of controlled and other hazardous areas (e.g., contamination zones and waste storage areas), discharge streams, and air and water permits are well marked and maintained as appropriate; and

- ensuring that emergency plans are in place, up-to-date, and accurate.

Assistant facility managers may be required to fulfill any or all of the above responsibilities upon request of the facility manager.

\subsection{ER HEALTH AND SAFETY REPRESENTATIVE}

The ER health and safety representative serves as a liaison between the installation health and safety disciplines and field operations personnel to address health and safety compliance and related issues. Responsibilities also include ensuring that appropriate logistical support is available and providing assistance in resolving problems.

\subsection{OFFICE OF SAFETY AND HEALTH PROTECTION REPRESENTATIVE}

The Office of Safety and Health Protection (OSHP) representative will ensure that appropriate technical oversight and field monitoring is provided as required for evaluating LMER employee exposures. Specific industrial hygiene (IH) and industrial safety support services may include the following: 
- review of appropriate project documents (e.g., HASP addenda, SWPs, and Field Change Orders);

- field surveillance as appropriate;

- on-site auditing for compliance with federal, state, and installation regulations, standards, and orders;

- collection and analysis of air samples for personal exposure modeling, when required;

- calibration and maintenance of instruments owned and operated by $\mathrm{IH}$;

- reporting of $\mathrm{IH}$ air and exposure monitoring results to employees and project management; and

- interpretation of federal, state, and installation regulations, standards, and orders.

\subsection{SAFETY AND HEALTH EVALUATION AND SUPPORT TEAM REPRESENTATIVE}

A representative of the ORNL Safety and Health Evaluation and Support Team (SHEST) will provide oversight and support services to any work involving subcontractor services, hazardous waste operations and emergency response, or construction activities. The SHEST representative will provide assistance in identifying, evaluating, and controlling risks associated with the activities that fall under SHEST's jurisdiction.

Currently, planned IFDP activities do not fall under the scope of 29 CFR 1910.120, Hazardous Waste Operations and Emergency Response (HAZWOPER). However, on a case-by case basis, at the request of project management SHEST will review project tasks to evaluate the potential for applicability of the HAZWOPER standard where any project task appears to involved hazardous waste operations. In the event that a task or activity is determined to fall under HAZWOPER, all requirements of 29 CFR 1910.120 and the ORNL HAZWOPER Program Manual (ORNL/M-2716) will apply to that task.

\subsection{OFFICE OF RADIATION PROTECTION}

The Office of Radiation Protection (ORP) will, in accordance with the ORNL Radiological Protection Procedure (RPP) Manual:

- conduct routine and special surveys of locations and operations associated with this project to determine radiological conditions;

- verify area radiological classifications and maintain records of surveys;

- designate radiological areas and determine or enact appropriate controls;

- survey and tag/label materials being moved from radiological areas;

- collect and analyze air samples and /or smears;

- review and approve operating procedures, work plans, technical documents, HASP addenda, Field Change Orders, and RWPs to ensure that the radiological controls are appropriate to the operations;

- conduct on-site auditing for compliance with federal, state, and installation regulations, standards, and orders;

- provide contamination monitoring of personnel or ensure instrumentation is available for personnel to monitor themselves; 
- provide and analyze external and internal dosimetry for personnel and report results of exposure monitoring, along with air sample analysis, smears, and other analyses to project managers and individual employees, when requested;

- ensure qualified radiological control technician (RCT) support is available for field work when required; and

- interpret federal, state, and installation regulations, standards, and orders concerning radiation protection.

The ORP area supervisors will provide day-to-day support and oversight of project activities conducted within their respective areas.

\subsection{PROJECT HEALTH AND SAFETY OFFICER}

The project health and safety officer (HSO) is responsible for making health and safety decisions and for specific health and safety activities. The project HSO has primary responsibility for the following:

- advising the project manager on health and safety issues;

- serves as the project interface with LMER environmental, safety, and health disciplines;

- verifying compliance with this HASP;

- reporting any incidents or deviations from anticipated conditions to the facility manager, project manager, and, where appropriate, applicable environmental, health and safety disciplines;

- ensuring that project personnel have access to this plan and are aware of its provisions;

- confirming that all project personnel have received the training listed in Sect. 4;

- ensuring that all chemicals are in appropriate, properly labeled containers;

- updating the HASP (through Field Change Orders or addenda) to ensure that it adequately identifies any new tasks or hazards and notifying the project personnel and LMER organizations that approved the plan of any changes; and

- controlling visitor access to the work area.

\subsection{PROJECT PERSONNEL}

All project personnel are responsible for

- performing only those tasks that they believe they can do safely;

- stopping work activities for any of the following reasons:

- inadequate health and safety controls,

- controls not being implemented,

- radiological control hold point's not being satisfied, or

- any imminent danger associated with the work activity;

- notifying the supervisor of any medical conditions (e.g., allergies, diabetes, or pregnancy) that require special consideration; 
- reporting all symptoms of exposure to chemical and physical hazards to their supervisor and the site Health Services Department;

- frisking or monitoring themselves for radioactive contamination prior to exiting the control zone;

- wearing PPE and personnel monitoring devices where required by RWPs, signs, procedures, this HASP, or by radiological control personnel and reporting immediately the loss, damage, or unexpected exposure of personnel monitoring devices or off-scale readings of self-reading dosimeters to the supervisor;

- maintaining radiological exposure as low as reasonably achievable;

- notifying radiological control personnel and the supervisor of off-site occupational radiation exposures, including any medically administered radiological exposures, and avoiding exceeding radiological administrative control levels; and

- discussing health and safety concerns with their supervisor and the project HSO.

\subsection{LABORATORY SHIFT SUPERINTENDENT}

The Laboratory Shift Superintendent (LSS) is the authorized individual who shall direct, control, and evaluate all site emergency response/emergency activities. The ORNL LSS shall be notified immediately of all site emergencies and/or occurrences. The ORNL LSS may be contacted by telephone at 574-6606 or by 2 -way plant radio at Station 103 . The emergency functions and responsibilities of the LSS shall include, but are not limited to, the following:

- Emergency response for fire, hazardous materials releases, radiological emergencies, security issues, energy and/or utility interruptions, medical assistance, site rescues, environmental monitoring, and damage control.

- Assuring the evacuation, emergency treatment, and emergency transport of personnel, and notifying emergency response units and the appropriate management staff.

- Requesting assistance from local authorities, if applicable.

- Acting as a liaison to off-site organizations as necessary (i.e., local police, fire departments, hospitals, etc.). 



\section{HAZARD ASSESSMENT}

The purpose of the hazard assessment is to identify and assess potential hazards that may be encountered by project personnel and to prescribe required controls. Work activities associated with this project have been in progress since fiscal year 1994. Deactivation has been completed or is near completion in several facilities, including Bldgs. 3029, 3030, 3031, 3118, 3033, 3033-A, 3034, 3028, 3099 , and 7025 . The remaining primary tasks that are to be performed at the additional facilities listed in Table 1.1. include

- removing hazardous chemical and radioactive material inventories (in a limited number of facilities),

- cleaning out the facilities,

- stabilizing the facilities structurally and radiologically,

- deactivating hot cells, and

- deactivating utilities.

The steps associated with these tasks are described in the following paragraphs. A detailed description of the tasks that will be performed in each facility can be found in the project work plan (ORNL/ER-249/R2). Each facility in the IFDP is unique in its purpose, historical use, potential contaminants, and operating equipment. The anticipated hazards associated with these tasks and methods to prevent or control exposure are addressed in task-specific procedures and safety documentation for each facility.

Potential hazards that may be encountered during this project include, but are not limited to,

- physical hazards such as compressed gases/cylinder, confined space, manual lifting, noise, temperature extremes, and tripping/falling;

- safety and construction hazards such as drum handling, electrical, elevated work, energized sources, excavation/penetration, hoisting/rigging, overhead hazards, and welding/cutting/burning hazards,

- chemical hazards such as asbestos, carcinogens, lead, metals, and polychlorinated biphenyls (PCBs); and

- airborne, radiation, and contamination ionizing radiological hazards.

Permits and additional project documents that may be required for this project include, but are not limited to, Excavation/Penetration Permit(s), Lockout/Tagout Permit(s), PACSEs, RWPs, SWPs, Welding/Hot Work Permit(s), and Asbestos Work Request(s). Applicable LMER procedures shall be identified and followed when conducting project work activities. The hazards, control measures, and required monitoring for the general project hazards and for individual tasks will be identified, evaluated and addressed on a case-by-case basis in the process depicted in Fig. 1., Hazards Analysis Process. Components of this process are described in Sect. 3.7 of this document. 


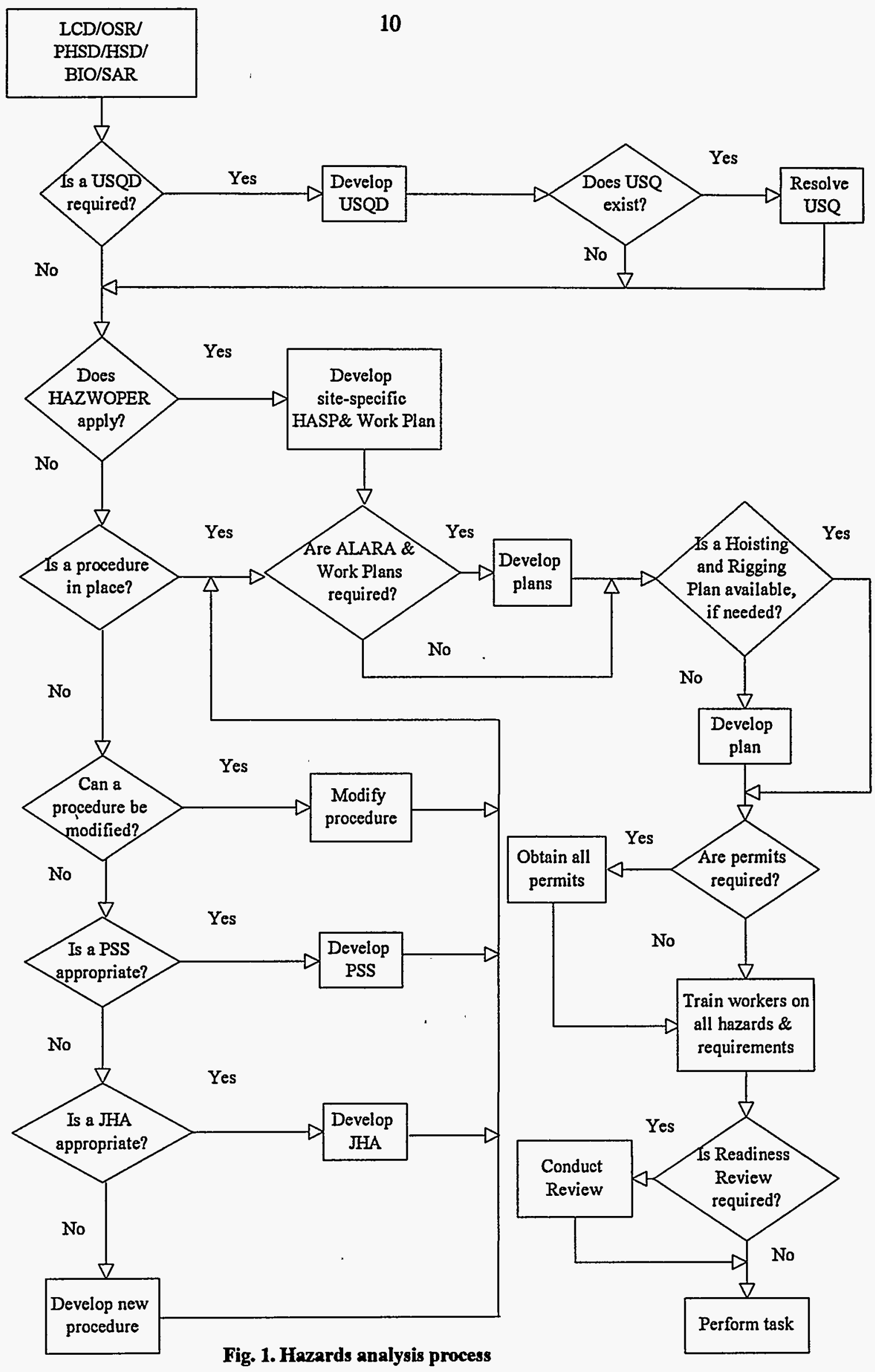




\subsection{REMOVAL OF CHEMICAL AND RADIOISOTOPIC INVENTORIES}

Chemical and radioisotopic inventories from the IFDP facilities have been consolidated in Bldgs. 3517, 3047, 3038, and 3026-D. The inventories in Bldgs. 3038, 3047, and 3026-D will be removed before these facilities are completely shut down. Existing procedures for removal and packaging of the inventories will be followed when there is no longer a potential for use of the inventories.

\subsection{FACILITY CLEANOUT}

The steps required for cleaning out each facility will vary based on the current contents and former use of the facility. General steps will include

- removing useable surplus equipment located throughout the facility;

- removing loose, unanchored equipment from potentially contaminated areas such as hot cells, hoods, and glove boxes; and

- characterizing, packaging and removing all wastes.

\subsection{FACILITY STABILIZATION}

The steps required to radiologically and structurally stabilize each facility may include

- removing transferable contamination from secondary containment systems,

- bonding and labeling fixed contamination,

- repairing primary containment systems,

- removing sources of potential airborne contamination from hoods and glove boxes,

- deactivating all services to hoods and glove boxes,

- sealing drains, and

- repairing roofs.

\subsection{DEACTIVATION OF HOT CELLS}

Hot cells will be cleaned by removing debris and wiping down surfaces to remove loose contamination. The following general steps will be performed during hot cell deactivation:

- remove all waste and loose equipment from the hot cell;

- wipe down surfaces to remove potential airborne contamination;

- stabilize primary containment (i.e., drain leaking windows);

- identify, label, and plug all service lines to the cell;

- replace manipulator boots and remove in-cell filters;

- plug all drains; 
- document final radiological condition of the cell; and

- secure all access to cell interior.

Manipulators will be repaired or replaced and maintained in place, which will minimize both waste and cost. The order of the steps will vary on a case-by-case basis. Unique, facility-specific procedures for deactivation of each type of hot cell will be followed.

\subsection{DEACTIVATION OF UTILITIES}

The following actions will be performed when utilities are being deactivated:

- deactivate all electrical circuits except those used in required monitoring systems,

- deactivate and drain all piping, and

- remove unnecessary instrumentation.

All water, steam (if practical), and gas piping will be disconnected at the supply header to each facility; and all lines will be drained. Radiation protection instruments and alarms will be removed, and all electrical service deemed non-essential to S\&M activities will be disconnected at the main breaker box.

\subsection{POTENTIAL CHEMICAL HAZARDS AND CONTAMINANTS}

Based on the historical use of each facility, potential contaminants would include residual radiochemicals or byproducts of the isotopes listed in Table 1.1. Additional chemical hazards during this project include materials used as shielding in hot cells such as oxidized lead bricks, and liquids such as $\mathrm{ZnBr}_{2}$ and mineral oil, which are contained in hot cell windows. In some facilities, nitric acid will be used to decontaminate surfaces in hot cells and glove boxes.

Work instructions and PPE for contact with each these materials are addressed in the related taskspecific procedure for each facility. If additional potential contaminants or hazardous chemicals, which pose a new or significantly greater hazard, are identified prior to or during project activities, they will be addressed in Field Change Orders, procedures, and/or other safety documentation after an Unreviewed Safety Question Determination (USQD) on the use of the chemical has been conducted.

Asbestos-containing materials (ACM) are known to be present in several of the IFDP facilities. An AWR will be generated and followed whenever ACM will be abated or disturbed during deactivation tasks in accordance with the Office of Safety and Health Procedure OSHP-012, "The Asbestos Oversight Management Program."

\subsection{SAFETY DOCUMENTATION}

The hazards associated with the IFDP work activities will be controlled through established safety documentation for each deactivation task within each facility. The types of facility-specific safety documentation in place at the IFDP facilities include ORNL-approved safety analysis reports (SARs), safety assessments, basis for interim operations (BIO)(submitted to DOE-ORO for approval), hazards screening documents (HSDs), and limiting conditions for operating documents (LCDs) and operational safety requirements (OSRs), as well as task-specific procedures which contain safe work practices and requirements. 
13

Table 3.1. Facility safety documentation

\begin{tabular}{|c|c|c|c|}
\hline Facility & $\begin{array}{c}\text { Operating } \\
\text { Controls } \\
\end{array}$ & Analysis & HSD Number \\
\hline $3026-C$ & LCD & HSD & HS/3026-C/F/RT-4/R1 \\
\hline 3026-D & LCD & HSD & $\mathrm{HS} / 3026 \mathrm{D} / \mathrm{F} / 92 / \mathrm{RO}$ \\
\hline 3028 & LCD & HSD & HS/3028/F/RT-5/R1 \\
\hline 3029 & LCD & HSD & HS/3029/F/RT-6/RI \\
\hline $\begin{array}{l}3030,3031, \\
3118\end{array}$ & N/A & HSD & $\begin{array}{l}\mathrm{HS} / 3030 / 3118 / 3031 / \mathrm{F} \\
\text { RT-7,-8,-22/R0 }\end{array}$ \\
\hline 3032 & N/A & HSD & HS/3032/F/RT-9/RO \\
\hline 3033,3093 & LCD & HSD & HS/3033/F/RT-10/RO \\
\hline 3033-A & N/A & HSD & $\mathrm{HS} / 3033-\mathrm{A} / \mathrm{F} / \mathrm{RT}-11 / \mathrm{R} 1$ \\
\hline 3034 & N/A & HSD & $\mathrm{HS} / 3034 / \mathrm{F} / \mathrm{RT}-12 / \mathrm{RO}$ \\
\hline $3038^{\circ}$ & OSR & BIO & HS/3038/F/RT-15/R1 \\
\hline 3047 & OSR & $\mathrm{BIO}$ & HS/3047/F/RT-16/R1 \\
\hline 3517 & OSR & I $\mathrm{BIO}$ & HS/3517/F/RT-29/R0 \\
\hline 7025 & LCD & HSD & HS/7025/F/RT-33/R0 \\
\hline $\begin{array}{l}\text { LCD=limit } \\
\text { BIO=basis } \\
\text { HSD=haza } \\
\text { OSR=oper } \\
\text { N/A=not a } \\
\text { Tncludes } 3\end{array}$ & $\begin{array}{l}\text { ions documer } \\
\text { operation } \\
\text { ng document } \\
\text { ety requireme } \\
-M \text {, and -E }\end{array}$ & & \\
\hline
\end{tabular}

As deactivation activities reduce or eliminate existing hazards at each facility, safety documentation such as BIO/SARs and OSRs will be replaced with lower-level safety documentation such as HSDs and LCDs. The BIO/SAR for Bldg. 3517 will remain in place as long as it is used as a site for storage of a significant amount of radioactive material. See Table 3.4 for a listing of the existing safety documentation for each facility.

Due to the unique nature of the location, tasks, and hazards associated with the activities for the IFDP, a graded approach for developing additional written health and safety documentation will be used by project management to ensure adequate identification, evaluation, and control of potential health and safety hazards. The additional documentation may include written procedures, a job hazard analysis (JHA), and/or a written health and safety plan. Where applicable, a task mock-up should be performed for non-routine tasks that are considered to present a medium to high risk of significant environmental, safety, or health hazards. 
When work activities are to be performed by CTD personnel and the task to be performed is nonroutine, performed infrequently, or new, or is otherwise inadequately addressed in existing division or facility-specific procedures, a detailed procedure will be developed by CTD along with appropriate assistance from workers, supervisors, project management, subject matter experts, and health and safety personnel. Each procedure will be written, reviewed, and approved prior to the start of work activities.

A JHA may be developed for a hazardous, non-routine, or new work activity as a preliminary part of the procedure development process or as a stand-alone approach to identifying and controlling safety and health hazards. The first step in developing a JHA is assembling a team whose members have direct knowledge of the steps and the location of the task to be performed and of the potential hazards. The objective of the JHA process is to identify the steps of the job, the associated hazards, and the preventive measures required to perform the task safely. The completed JHA should be implemented by modifying job conditions or equipment based on the preventive measures identified, in job orientation and training, in the preparation of job instructions, and/or in developing a written procedure for the task. Guidance for the development and implementation of a JHA can be found in Lockheed Martin Energy Systems Work Instruction SH-1 18INS, "Job Hazard Analysis" or ORNL equivalent.

When work activities will be performed by a subcontractor organization, the process detailed in PC-164, "Service Subcontract Safety and Health," or ORNL equivalent will be followed. At the discretion of project management and SHEST, a job-specific written HASP also may be required.

\subsubsection{Safety Documentation Manuals}

A unique combination of these types of safety documentation is required for each facility. A controlled notebook containing the required safety documentation is maintained for each facility by the facility manager. This safety documentation includes facility-specific task and general operating procedures, HSDs, LCDs, and OSRs. Where in existence, BIOs and SARs are also included in the safety documentation manuals. Some facility general operating procedures also contain facility checksheets, which must be completed daily or weekly. Thorough training of personnel on the requirements of the safety documentation is required prior to conducting any deactivation task.

Bldgs. 3038, 3047, and 3517 are categorized as nuclear facilities. The safety documentation for each of these facilities is contained in a Facility Authorization Basis.

\subsubsection{Problem Safety Summaries}

Problem Safety Summaries (PSSs) are required by the Safety Manual for the Radiochemical Technology Section of the Chemical Technology Division (ORNL/CF-96/I) for every significant experimental problem, process, or laboratory not covered elsewhere by procedure or other forms of safety documentation. PSSs are required to be conspicuously available in the work area and to be revised and to undergo review and approval at every significant change. At a minimum, PSSs are revised or reapproved every 12 months. 


\subsubsection{Unreviewed Safety Question Determination}

Any proposed change to the physical or procedural elements within IFDP facilities and any new project activities or experiments will undergo the Unreviewed Safety Question Determination (USQD) process, as detailed in ORNL procedure FS-102,"Unreviewed Safety Question Determinations." The intent of this review is to determine the impact of the anticipated change and to ensure that appropriate operation restrictions, if warranted, and safety documentation are in place. The facility manager will review proposed activities or changes to determine if the USQD process should be applied.

\subsubsection{As Low As Reasonably Achievable Plans}

As Low As Reasonably Achievable (ALARA) Plans will be developed for any project activity meeting the criteria established by RPP-138, "ORNL As Low As Reasonably Achievable Program."

\subsubsection{Other Work Plans}

Work plans for specific tasks will be developed at the discretion of project management and facility managers as a best management practice or where required by internal procedures, federal orders, or regulatory standards.

\subsubsection{Hoisting and Rigging Plans}

In a limited number of the IFDP facilities, project activities involving deactivation of hot cells may require hoisting and rigging. These activities have been evaluated, and Hoisting and Rigging Plans have been developed for the facilities in which such plans are required under the provisions of Energy Systems procedure SH-115PD, "Hoisting and Rigging Program," and the DOE Hoisting and Rigging Handbook.

\subsubsection{Permits}

Additional task- or area-specific permits that may be required for this project include, but are not limited to, Excavation/Penetration Permit(s), Lockout/Tagout Permit(s), PACSEs, RWPs, SWPs, Welding/Hot Work Permit(s), and Asbestos Work Request(s). Applicable ORNL procedures for obtaining and following each permit shall be followed by project management and other project personnel. 


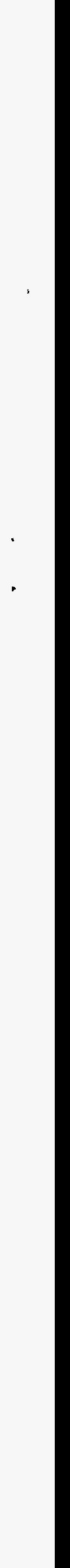




\section{TRAINING REQUIREMENTS}

\subsection{GENERAL TRAINING REQUIREMENTS}

Personnel who enter the work area during this project are subject to the following training requirements. These summaries include a course description and guidance on who must take each course. Table 4.1 presents the requirements in condensed format.

Energy Systems General Employee Training (GET) is required for all employees and any visitor who enters the controlled area of ORNL to perform work for more than 10 working days per year. This training addresses general site features and hazards, alarm signals, and evacuation.

Energy Systems Radiological Worker II training (Rad Worker II) is required for unescorted entry into radiological areas. This training is designed to enable those who attend to work safely within a radiologically contaminated area. It lasts 20 hours and includes donning/doffing, frisker, and general techniques for contamination control.

General hazard communication training is required for all project workers. This training must communicate the risks and protective measures for chemicals that employees may encounter. This requirement is met by taking GET and any appropriate task hazard briefing. This training must be refreshed as needed to maintain currency with the chemical hazards present on the job site.

The Hazardous Waste Operations and Emergency Response (HAZWOPER) 40-hour worker training course may be required for workers who will be conducting hands-on work during this project. Twenty-four hours of relevant field experience is required in conjunction with this training. Note that HAZWOPER training is required for LMER personnel only as a best management practice; the project does not fall under the requirements of Title 29 of the Code of Federal Regulations (CFR) Part 1910.120. In the event that a specific portion of this project or a specific task is determined to fall under the requirements of 29 CFR 1910.120, HAZWOPER 40-hour, 8-hour, and site supervisor (as applicable) training courses will be mandatory for personnel conducting work on the designated task or activity.

The HAZWOPER 8-hour annual refresher course is required to maintain currency in the 40-hour and 24-hour courses. It must be repeated annually by anyone who is required to have either of these courses.

The HAZWOPER site supervisors training may be required for all personnel who directly supervise hands-on workers. This is an 8-hour course that must be taken once. Note that the HAZWOPER 40hour course is a prerequisite.

Waste generation training is required for personnel who are responsible for the generation and satellite storage of any hazardous waste. This training addresses the legal and operational requirements for the proper storage and labeling of hazardous waste.

Respiratory protection training is required for all individuals who wear respirators. It includes the basic procedures for proper respirator use. This training must be refreshed on an annual basis. Respirator users must also have medical clearance to wear respirators and must have passed a quantitative respirator fit test with the size and type of respirator to be used. 
Respirator issue training is required for any individual who issues respiratory protective devices. This training includes the information in respiratory protection training as well as the requirements for proper storage, issuance criteria, and use limitations.

Site-specific hazard communication training is required for all personnel assigned to the project. It includes the identifying potential chemical exposures, the symptoms of exposure, and appropriate protective measures.

Safety briefings will be held when conditions or tasks change. These briefings will be conducted by the project HSO and/or supervisor and will be attended by all project workers and supervisors. These briefings will address activity-specific safety issues and will be used as an opportunity to refresh workers on specific procedures and to address new hazards and controls.

Additional training may be required for project workers based on the inherent hazards of each facility or task. This training may include, but is not limited to, subject areas such as fire extinguisher usage, confined space entry, Department of Transportation requirements, Criticality Safety, and lockout/tagout.

\subsection{EMERGENCY ACTION PLAN TRAINING}

Project workers will be trained in facility emergency action plans, including response to incidentalreleases of hazardous substances that occur within the boundary of the work area. An incidental release is one that can be controlled at the time of the release by employees in the immediate release area or by maintenance personnel. Workers will not participate in emergency response operations as defined in 29 CFR 1910.120 (a)(3). An emergency response is defined as a response outside the facility or to an occurrence that is likely to result in an uncontrolled release of a hazardous substance. The emergency action plan for the project is described in Sect. 10 of this document.

\subsection{VISITOR TRAINING}

Project visitors who infrequently enter the project work areas and have a limited potential for exposure to chemical, physical, or radiological hazards are subject to different training requirements than project workers. All visitors will be escorted by fully trained project workers at all times. Visitors who will be on-site for less than 10 days within a calendar year are not required to received any formal training. Visitors are required to complete GET if they are on-site for more than 10 days. Examples of these types of visitors are auditors, photographers, management personnel who do not directly supervise on-site workers, technical specialists who need to gather data, and others. 


\section{PERSONAL PROTECTIVE EQUIPMENT}

The selection of PPE for tasks is based on potential location-specific physical, chemical, and radiological hazards. In cases where multiple hazards are present, a combination of protective equipment will be selected so that adequate protection is provided for each hazard. When a conflict exists with the PPE requirements, the more restrictive will apply. For example, heavy-duty polyvinyl chloride (PVC) gloves are acceptable substitutes for leather work gloves for cut and abrasion protection; disposable coveralls are acceptable substitutes for cloth anti-contamination coveralls; chemical-resistant, punctureresistant, disposable gloves are acceptable substitutes for anti-contamination gloves; nitrile or butyl rubber boots are acceptable substitutes for anti-contamination shoe covers. This section emphasizes the programmatic requirements for PPE. For task-specific PPE, see the corresponding procedures for each task and any task-specific work permits. Task-specific work permits take precedence over any PPE selection described in this HASP.

\subsection{PPE SELECTION}

Several general rules apply to the selection of protective clothing. The type of protection selected for a particular task is based on the following:

- potential for exposure because of work being done;

- route of exposure;

- measured or anticipated concentration in the medium of concern;

- toxicity, reactivity, or other measure of adverse effect; and

- physical hazards such as falling objects and flying projectiles.

In situations where the type of chemical or radioisotope, the concentration, and the probability of contact are not known, the selected level of protection must be based on professional experience and judgment of the RCT and the project HSO until the hazards are further evaluated. In addition, the OSHP representative and other LMER health and safety disciplines may be contacted for their recommendations in the PPE selection process. Criteria indicating a possible need for reassessment of the PPE selection include the following:

- beginning of an unplanned (hazard not previously assessed) work phase;

- working in unanticipated temperature extremes;

- encountering new hazards;

- exceeding the action limits of chemical/radiological hazards; or

- changing the work scope so that the degree of contact with contaminants changes. 


\subsection{LEVELS OF PROTECTION}

The required levels of protection used to protect against chemical and physical hazards during this project are specified in task- and facility-specific procedures or will be identified on RWPs or SWPs. The PPE worn by the project personnel in radiological areas will, at a minimum, be consistent with the installation anti-contamination clothing policy for the area radiological classification. Protective clothing designated for radiological control use will be yellow. Protective clothing designated for radiological control use will not be used for non-radiological work. PPE and clothing will not be stored with company-issue or personal street clothing.

\subsection{PROTECTIVE CLOTHING DONNING AND DOFFING PROCEDURES}

Project personnel shall follow ORNL-approved donning and doffing procedures unless otherwise instructed by task-specific RWPs, procedures, or plans. Any variations from ORNL donning and doffing procedures must be agreed upon in advance by consensus of applicable project and site personnel including the job or task supervisor, the project HSO, the OSHP representative, ORP representatives, and other appropriate safety and health disciplines.

\subsection{RESPIRATORY PROTECTION}

Work requiring respiratory protection shall be performed by LMER personnel in accordance with OSHP-006, "The ORNL Respiratory Protection Program." For effective integration of the requirements of this procedure into subcontractor activities, respiratory protection program requirements will be identified by SHEST and project management in contract specifications. 


\section{MEDICAL SURVEILLANCE}

The purpose of a medical surveillance program is to assess and monitor the health and physical condition of personnel working with hazardous substances or have the potential for encountering health hazards.

All employees who are in a medical surveillance program will receive a medical examination prior to assignment, annually, and at termination unless the attending physician believes a shorter or longer interval (not to exceed 2 years) is appropriate. An annual physical is mandatory for fissile material workers. Additionally, those who are suspected of having been exposed to unexpected releases of hazardous waste will receive an examination and consultation as soon as possible following the incident or development of signs or symptoms and at additional times when the examining physician determines that follow-up examinations or consultations are medically necessary.

\subsection{MEDICAL EXAM CONTENT}

Medical examinations will include a medical and work history evaluation, a complete physical examination, and necessary tests according to the protocol of the medical organization providing the service. Employees will have access to the results of the medical examination and to explanations of the tests and findings.

\subsection{MEDICAL SUPPORT}

The ORNL Fire Department, which operates an ambulance service staffed by emergency medical technicians 24 hours a day, will provide medical support. A medical staff of physicians and nurses are available during the day shift at the Site Health Services Department for additional support. Injured personnel will be transported to the Oak Ridge Methodist Medical Center by ambulance during evening work shifts. 



\section{EXPOSURE MONITORING AND AIR SAMPLING}

Assessment of airbome chemical concentrations, airborne radiological concentrations, and surficial radiological contamination levels will be performed, as necessary, to ensure that exposures do not exceed permissible levels. The deployment of monitoring equipment will depend on the activities being conducted and the potential exposures.

The RCT will conduct surveys to include pre-entry, equipment, and area surveys. All radiological assessments and activities shall be performed in accordance with the ORNL Radiological Protection Procedure (RPP) Manual. The following types of routine monitoring will be required for radiological contamination areas:

- All personnel will monitor or be monitored for radioactive contamination prior to exiting contamination areas.

- All personnel entering the site will participate in the installation's dosimetry program. Thermoluminescent dosimeters shall be worn at all times while on-site. In addition, individuals working in Bldg. 3038 may be required to wear a neutron dosimeter.

- All personnel participating in hands-on work in radiological contamination areas will participate in the installation's bioassay program as required by the ORNL RPP Manual.

- All equipment and materials will be monitored for radiological contamination before being removed from any radiological contamination areas.

Additional monitoring, sampling, or observation may be conducted at the discretion of the OSHP representative for CTD or when required by ORNL procedures. This monitoring would be based on the hazards presented by the task being performed. Examples of this monitoring include sound level assessment, noise dosimetry, wet bulb globe temperature readings, and personal exposure sampling. All IH sampling will be conducted in accordance with OSHP-024, "Monitoring Program," which outlines the approach to all area and personal monitoring/sampling activities to evaluate employee exposures and to determine if exposure exceeds permissible limits or action levels.

All asbestos-related work will be conducted in accordance with OSHP-012, "The Asbestos Oversight Management Program," which includes area and personnel monitoring requirements when working with $\mathrm{ACM}$. 


\section{SITE CONTROL}

Access to IFDP facilities will be controlled by existing means of access restriction, as described in the RTS Safety Manual (ORNL/CF-96/1). Access is limited to personnel having a need to enter the facility and who have completed appropriate, site-specific training for that facility. Access is controlled by badge readers, where available, and by door locks with a limited number of key holders. A listing of individuals who are authorized to enter a facility will be posted at all entrances of facilities without badge readers. Instructions for gaining entry to a facility are also posted at all entrances.

\subsection{CONTROL ZONES}

Appropriate control zones will be established, as necessary, around areas that present physical, chemical, and/or radiological hazards. The requirements of the ORP procedures, plans, and permits will be followed when control zones are being established for radiological areas. For a map of the ORNL site and each of the IFDP facilities, see Appendix A, "Description and History of Facilities," of the project work plan (ORNL/ER-249/R2).

\subsection{VISITORS}

Visitors to the project will abide by the following:

- Visitors must have approval from the facility management to enter each facility and must receive an appropriate level of facility access training.

- Visitors must have proper dosimetry, arranged through the appropriate Division Radiological Control Officer.

- Visitors will be escorted at all times by project personnel.

- Visitors will be instructed to stay outside active work areas during the extent of their stay, unless entry has been approved by the facility management.

- Visitors requesting to enter hazardous areas must wear all appropriate PPE for entry and abide by the appropriate work rules. If respiratory protective devices are necessary, visitors must produce evidence that they have medical approval for respirator use, have respirator training, and have been fit tested for the type and size of respirator to be used within the past 12 months. See Sect. 4 for visitor training requirements. 



\section{DECONTAMINATION}

A system of procedures will be used to control the spread of contamination and to ensure that workers are sufficiently free of contamination to preclude adverse health effects. PPE doffing and personnel decontamination are part of this system. Routine procedures will include "frisking" upon departure from radiological contamination areas to verify acceptable levels of surface contamination. Detectable contamination found on skin or personal clothing will require notification of the ORP and decontamination. ORP personnel will supervise and assist in decontamination in accordance with the ORP procedure RPP-540, Rev. 1, "Handling Radiologically Contaminated Personnel."

Personnel will follow standard ORNL PPE doffing procedures for radiological contamination areas unless otherwise instructed by RCTs. If frisking indicates contamination of personnel, existing ORNL personnel decontamination procedures will be implemented.

Decontamination tasks and operations, which are planned as a part of the facility deactivation process, will follow existing approved facility-specific procedures. 


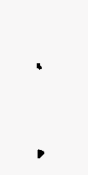




\section{EMERGENCY RESPONSE/ACTION PLAN}

In the event of an emergency, all project personnel shall follow the requirements and provisions of the ORNL X-10 Site Emergency Plan (ORNL/CF-91/71/R2, September 1994). Emergency response will be provided by the ORNL emergency response organization. The work supervisor will be in charge of personnel accountability during emergency activities. All personnel working on the project will be trained to recognize and report emergencies in accordance with ORNL plans and procedures and the RTS Safety Manual (ORNL/CF-96/1).

This section serves as a emergency action plan for the project. This emergency action plan will be reviewed periodically. The requirements of this section will be communicated to project workers. Any new.hazards or changes in the plan will also be communicated to project workers.

\subsection{EMERGENCY RESPONSE}

The ORNL emergency response organization will be contacted for emergency response to all fires, personnel injuries, chemical spills that cannot be controlled by project personnel, or other significant emergencies. The LSS coordinates 24-hour emergency response coverage from the Plant Protection and Shift Operations Division. The LSS is assisted by a well-trained plant emergency squad and is the overall coordinator responsible for directing the response to emergencies.

\subsection{LOCAL EMERGENCY MANUALS AND ACTION PLANS}

As in all ORNL buildings, a local emergency manual, which contains explicit instructions and information about required emergency actions and procedures, is located near entrances of each facility. Each manual contains the facility-specific information such as the following:

- criteria and instructions for emergency notifications, including telephone numbers;

- responsibilities in emergency events;

- required responses during emergencies such as fire, explosion, natural disasters, radiation incidents, and accidental releases;

- instructions for accountability of personnel, evacuations, and sheltering in place;

- identification of major credible emergencies for the facility and procedures for addressing each situation;

- a matrix of emergency action levels;

- guidelines for rescue of personnel and instructions for handling injuries and contamination of personnel;

- inventories of materials stored within the facility;

- facility maps; and

- instructions for building re-entry. 
All employees are required by the RTS Safety Manual to be familiar with the plan contents for the facility in which they will be working. If the emergency situation is classified as an occurrence, OP-301, "Occurrence Notification and Reporting," shall be followed.

\subsection{ASSEMBLY POINTS}

There are four designated local assembly points for the IFDP facilities: (1) the assembly point for the Isotope Area, (2) the assembly point for Bldg. 3517, (3) the assembly point for Bldg. 7025 . Local assembly points are marked with signs with a large orange circle on a white background, and (4) the assembly point for Bldgs. 3026-C and 3026-D. 


\section{REFERENCES}

ACGIH (American Conference of Governmental Industrial Hygienists), 1995. 1994-1995 Threshold Limit Values for Chemical Substances and Physical Agents and Biological Exposure Indices.

DOE (U.S. Department of Energy), 1993. Annotated Outlines for Documents Required by FFA and Energy Systems (Martin Marietta Energy Systems, Inc.) 1990. Management Plan for the Oak Ridge Operations Environmental Restoration Program, DOE/ORO-931, Oak Ridge, Tennessee, December.

Lockheed Martin Energy Systems (LMES), 1996. Project Management Plan for the Isotopes Facilities Deactivation Project at Oak Ridge National Laboratory (ORNL/ER-230/R1).

LMES, 1996. Safety Manual for the Radiochemical Technology Section of the Chemical Technology Division (ORNL/CF-96/1).

LMES, 1996. Work Plan for the Isotopes Facilities Deactivation Project at Oak Ridge National Laboratory (ORNL/ER-249/R2).

NIOSH (National Institute for Occupational Safety and Health), 1990. Pocket Guide to Chemical Hazards, U.S. Department of Health and Human Services, Public Health Service, Centers for Disease Control, June. 


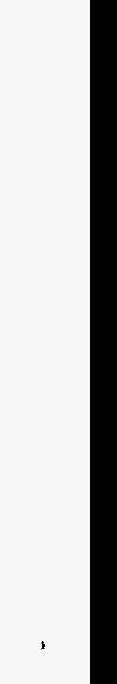




\section{DISTRIBUTION}

1. L. V. Asplund

2. R. A. Brown

3. T. Burwinkle

4. C. Clark, Jr.

5. K. Constant

6. R. E. Eversole

7. K. R. Geber

8. K.W. Haff

9. D. W. Malkemus

10. D. M. Matteo

12. B. A. Owen

13-14. P. T. Owen

15. L. D. Owens

16. R. S. Owens

17. B. D. Patton

18. H.X. Phillips

19. P. A. Schrandt

20. R. R. Shoun

21. D. A. White

22. Central Research Library

23. ER Document Management Center-RC

24. Office of Scientific and Technical Information, P. O. Box 62, Oak Ridge, Tennessee 37831 